Fig. 5. Bairdia formosa, seen from left side.

Fig. 6. The same, seen from above.

Fig. 7. The same, seen from the front.

Fig. 8. Loxoconcha alata (male), seen from left side.

Fig. 9. The same, seen from above.

Fig. 10. The same, seen from below.

Fig. 11. The same, seen from the front.

Fig. 12. The same (female), seen from left side.

Fig. 13. The same, seen from below.

Fig. 14. Cythere crispata, seen from left side.

Fig. 15. The same, seen from above.

\title{
Plate XV.
}

Fig. 1. Paradoxostoma (?) reniforme, seen from left side.

Fig. 2. The same, seen from above.

Fig. 3. Cytherura acris (male?), seen from left side.

Fig. 4. The same, seen from above.

Fig. 5. Cythere faraides (male), seen from left side.

Fig. 6. The same (female), seen from left side.

Fig. 7. The same, seen from above.

Fig. 8. Cythere Speyeri (male), seen from left side.

Fig. 9. The same (temale), seen from left side.

Fig. 10. The same, seen from below.

Fig. 11. The same, seen from the front.

Fig. 12. Cythere dissimilis, right valve, seen from the side.

Fig. 13. The same, seen from above.

[All magnified 40 diameters.]

XXV.-Observations on the Classification of Echinida, to serve as an Introduction to the Description of the Tertiary Fossil Echinodermata of Western Algeria. By A. POMEL*.

I HAVE had the honour to present to the Academy a series of lithographic drawings representing some fossil Echinodermata from Algeria, which are to form a part of the palæontology of that country. The descriptive part of the work is not yet printed; and I now submit to the judgment of the Academy the introduction to this work, in which I propose certain modifications in the classification followed by authors.

The number of the series of coronal plates, sometimes twenty, or two in each area, in the true Echinida, sometimes much greater by their multiplication in the interambulacral areas, and even in the ambulacral areas in the Tessellata, gives a first division, of the rank of a suborder.

The Echinida present three types, which advance regularly from the bilateral to the radial symmetry, and which I name Spatiformes, Lampadiformes, and Globiformes. The first have the mouth placed very eccentrically in front, and the anus behind; the obliteration of the anterior ambulacrum

* Translated from the 'Comptes Rendus,' Aug. 3, 1868, pp. 302-305. 
and the obovate form mask the radial symmetry for the benefit of the bilateral. The second have the mouth central or nearly so, the ambulacra similar, and the anus more or less posterior, but often mounting high enough to enter into the series of the genital pieces, which open behind to receive it. The third have the mouth central and the anus opposite, always completely enclosed by the genital apparatus. This division appears to us more natural than the division into two groups of regular and irregular forms, the distinctive character of which is not so absolute as it has been represented.

The Spatiformes or Spatangödes form two groups, according as their ambulacra are constituted by simple pores throughout their whole extent (Ananchytida), or as these ambulacra are petaloid (Spatangi). The homogeneity of the family of true Spatangi is such that no one has yet supposed that it could be subdivided; however, an attentive study permits us to recognize and even to define in it several new well-marked groups.

1. The Eupatagia have the madreporic tubercle prolonged behind between the ocellar pieces in the place of the unpaired genital plate; their petals are even with the test, and provided on the interporiferous area with tubercles like those of the other areas; we may further separate in it the type with an internal fasciole (Breynia), that with lanceolate petals (Eupatagus), and that with sublinear petals (Trachyspatagus).

2. The Brissia are like the foregoing, as far as the madreporide goes; but their petals are depressed, well-defined, and with an interporiferous zone provided only with granules. Some have the tubercles of the back heterogeneous (Leskia); others have them almost homogeneous, and their periprocta is remarkably open (Brissus); others have some small, oblique, closely approximated dorsal tubercles and a moderate periprocta (Brissopsis).

3. The Micrasteria have the apical apparatus compactthat is to say, with the madreporic tubercle in the centre of the genital plates, which are contiguous. The tubercles of the back are most frequently scattered amidst an abundant granulation. The ambulacra are depressed and well defined. Almost all the genera have fascioles.

4. The Toxasteria have the apex compact, and some scattered dorsal tubercles; but their petals are even with the test, and the anterior ambulacrum has linear pores, either alone or mingled with round pores. The peristome is not so boldly labiated as in the other Spatangoïdes. There are no fascioles. 
5. The Holasteria have the apex lengthened in consequence of the intercalation of the ocellar pieces between the genital pieces. The petals are still even with the test, with the pores but slightly developed in most of them. Some fascioles may be seen at the ambitus. In some the apex is continuous (Holaster); in others it is disjointed, and there are, as it were, two ambulacral summits (the sole genus is Metaporinus).

The Ananchytida are divided into two groups: the first, with the apex elongated, Offaster; the second, with the apex compact, Stenonia.

The Lampadiformes are either edentate or furnished with teeth. The former are divided into the Echinoneida, with a mouth without tubercle, or floscule, and with simple or subpetaloid ambulacra; and Cassidulida, furnished with a floscule and tubercle at the mouth, and with petaloid ambulacra. The second are divided into the Clypeastroida, with petaloid ambulacra, and the Echinoconida, with simple ambulacra.

The Echinoneida comprise three types:-

1. The Dysasteria are still almost spatiform, and many authors have united them with the Ananchytida; but they have the ambulacra of the Lampadiformes on the inferior surface; their ambulacral summit is disjointed in the true Dysaster, and simply elongated in Hyboclypus.

2. The Echinonea have the ambulacra simple and uniform from the mouth to the apex, which is compact; the peristome is often oblique; of fossil genera Pyrina may be cited.

3. The Caratomia also have their apex compact, but their ambulacra pass into the petaloid form ; they are almost simple in Caratomis, subpetaloid and unequal in Asterostoma, and petaloid in Pygaulus.

The Cassidulida are those of authors, less the Caratomia. Some have a very rudimentary floscule between the cushions, and the petals are dissimilar in Archiaria, similar in Clypeus; others have a well-developed floscule, with conjugated pores in Pygurus, non-conjugated pores in Echinanthus; and a fifth phyllodean type is remarkable on account of the shortness of the petals, Faujasia, foreshadowing the following. type.

'The Clypeastroida remain, divided into Clypeastres, Scutella, and Lagana. However, it would be perhaps convenient to divide the last-mentioned group into true Lagance, with a buccal rosette and petaloid ambulacra, and Echinocyami without buccal rosette, and with ambulacra hardly petaloid, and formed of non-conjugate pores.

The Echinoconida are, again, those of authors, less the tooth- 
less types. Some have the anus far from the apex; the peristome is small and but slightly angular in Echinoconus; it is large and strongly notched in Pygaster; others have the frame of the periprocta partly constituted by the genital circleEchinoclypus ; and as the peristome is strongly notched, there is a manifest passage to the type of the regular Echinida.

The Globiform Echinida are very homogeneous, but yet they can be divided into two distinct subfamilies, the Cidarida, with the ambulacra prolonged on the buccal membrane, and destitute of buccal branchix, and the Echinida, with the ambulacra not prolonged, but provided with buccal branchiæ, applied against the frame of the peristome in a more or less deep notch.

The Cidarides are only varied in a slight degree; some have the ambulacra flexuous-Temnocidaris and Cidaris. Others have the ambulacra straight, and the tubercles relatively small-Orthocidaris and Diplocidaris.

The Echinides are, of all the Echinida, those in which the serial arrangement is most difficult to find. We have decided to make two groups of them, the perforation of the mamilla of the tubercles being characteristic of the Diademia and wanting in the Echinia.

The Salenia have been raised into a tribe, and even into a family, because one of the pieces which, in the ordinary Echinida invest the anal membrane, is in this case fixed to the test, and also because the anus is eccentric in the periproctal frame, as is the case in many other living types. It is therefore probable that this tribe will be suppressed, or perhaps be distributed among the others.

The Diademia include several types; Heterocidaris, with short ambulacral lips and a small peristome; Hemicidaris, with a large, diagonal peristome, and with very narrow ambulacra; Diadema differing from these by its tubercles being equal in the two areas; and Pedina with a small peristome, much notched, and with slightly developed tubercles.

The Echinia are a little more varied; the peristome has its lips but slightly unequal, and its notches sharp in some; the test has no sculpture, and the tubercles of the two areas are unequal in Eropeltis, subequal in Phymasoma and Coelopleurus; the test is ornamented with sculpture and impressions in Temnopleurus and Salmacis. The peristome has no notches, or very slight ones, and the lips are very unequal in Codechinus, equal in Psammechinus. Its notches are very clean, and even deep, and the lips very unequal, in Magnosia and Stomechinus. The peristome is almost round, and the notches are narrow and deep in Tripneustes. Lastly, with 
the peristome of Phymasoma we have the ambulacra almost petaloid at the base in Heliocidaris and Acrocladia.

It may be remarked that the above classification arranges the Echinida in two continuous series, namely, the toothless and toothed; all that was necessary to obtain this incontestable improvement was to refer the Echinonea to their proper place.

\section{MISCELLANEOUS.}

On a Collection of Pteropods and Heteropods.

By F. P. Marrat.

THe following collection of Pteropods and Heteropods was obtained by Capt. Whiteway, of the ship 'Annie Cheshyre,' during several voyages from Liverpool to Valparaiso. This gentleman has been in the habit of collecting various marine objects, and with the utmost liberality has given them to our local museums and private collectors. It is truly surprising to find what a very large number of interesting specimens have been procured by the indefatigable exertions of a single individual. The following list comprises only one section of his work. The specimens were placed in my hands, and were found to include the following species:-

\section{Pteropoda.}

Cavolina tridentata, Forsk.

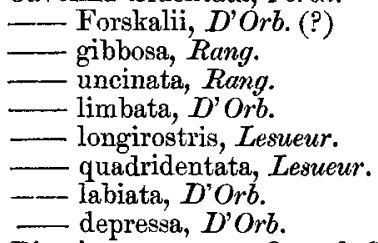

Diacria mucronata, Quoy \& Gaim.

C. trispinosa, Lesueur.

Clio cuspidata, Bosc.
Clio lanceolata, Lesueur.

pyramidata, Browne.

Balantium recurvum, Children.

Styliola recta, Lesueur.

- corniformis, D'Orb.

- subulata, Quoy \& Gaim.

- virgula, Rang.

Triptera columnella, Rang.

Spirialis rostralis, Eyd. \& Soul.

inflata, D'Orb.

- rotunda, $D^{\prime} O r b$.

Heterofusus bulimoides, $D^{\prime} O r b$.

\section{HETEROPODA.}

Ianthina bifida, Nuttall.

_- communis, Lam.

- globosa, Swain.

_- exigua, Lam.

_ fragilis, Lam.

Atlanta brunnea, Eyd.

- inclinata, Eyd.

_- Peronii, Lesu. \& Blainv.
Atlanta rosea, Eyd.

- involuta, Eyd.

-_Lesueurii, Eyd.

_ inflata, Eyd.

- turricula, $D^{\prime} O r b$.

Oxygyrus Keraudrenii, Rang .

Carinaria cymbium, Linn.

2 Peveril Terrace, Edge Lane, Liverpool. August 12, 1868. 